\title{
UNFAIR COMPETITION: APPROPRIATION OF TRADE SECRETS HELD TO CONSTITUTE CONTINUING TORT FOR PURPOSE OF STATUTE OF LIMITATIONS
}

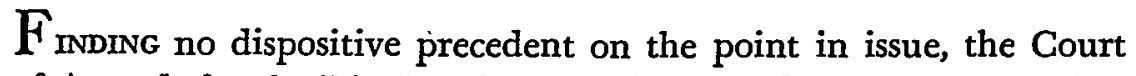
of Appeals for the District of Columbia in Underwater Storage, Inc. $v$. United States Rubber Co. ${ }^{1}$ held that even though the statute of limitations had run on the original taking of a trade secret, the misappropriators were still amenable to suit in tort for each use of the secret within the statutory period of limitations immediately preceding the initiation of the action. The developer alleged that United States Rubber Co. had unlawfully acquired an underwater system for the storage of strategic materials developed in 1958 by obtaining knowledge of the system from a person to whom the information had been entrusted in confidence. Two years later the developer became aware of the unlawful acquisition when the alleged misappropriator published the trade secret, but no complaint was filed until. 1964. United States Rubber Co. moved for summary judgment pursuant to rule $56,{ }^{2}$ asserting that the developer's claims were barred by the three-year statute of limitations on tort actions. ${ }^{3}$ Accordingly, the district court defined the issue as whether a misappropriator's use of a trade secret constitutes a continuing tort or whether the wrong is complete at the time of the original taking of the secret. The court held that the tort lay in the wrongful acquisition and, consequently, that the action was barred by the three-year limitation period. Subsequently, the court of appeals reversed.

Generally, a trade secret may consist of any formula, pattern, device, or data which gives the developer an opportunity to gain an advantage over competitors who are not privy to the information. ${ }^{4}$ The law provides protection for trade secrets because of a prevailing public policy which demands fair dealing in business relationships. ${ }^{5}$

1151 U.S.P.Q. 90 (D.C. Cir. 1966), cert. denied, 87 Sup. Ct. 859 (1967).

2 FED. R. Crv. P. 56.

${ }^{3}$ D.C. CODE ANN. § 12-201 (1961).

1 Restatement, Torts $\$ 757$, comment $b$ (1939). See generally Ellls, Trade Secrets $\S \S 1-37,66-82,181-223$ (1953).

- See E. I. duPont deNemours Powder Co. v. Masland, 244 U.S. 100, 102 (1917); Ellis, Trade SECRETS $\$ 8$ (1953). See generally Cummings, Some Aspects of Trade 
On a practical plane, the courts implement this policy by striking a balance between the need to facilitate mobility of ideas and the desire to give reasonable security to the owner against unauthorized use or acquisition of his trade secrets by former confidants or competitors. ${ }^{6}$ The courts favor mobility of ideas when the secret is discovered or disclosed by proper means which do not evidence an intent to deprive an owner of his exclusive processes. ${ }^{7}$ On the other hand, the balance is struck in favor of the owner's right to protection if the secret is obtained by theft, bribery, stealth, breach of a confidential relationship, or other similar means which may fairly be characterized as "unlawful." 8 In the latter circumstance, the improper acquisition does not deprive the secret of its confidential nature and protected status. ${ }^{9}$ Beyond these seemingly settled equitable principles, however, is the conceptual nature of the wrong, a question which becomes crucial when, as in Underwater Storage, an issue arises as to the applicable statute of limitations.

Statutes of limitations are basically designed to keep stale and vexatious claims out of court. ${ }^{10}$ Therefore, if an injured party does not bring suit within a fixed period of time after the harm occurs, he is forever barred. ${ }^{11}$ The critical determination thus becomes the

Secrets and Their Protection: The Public Domain and the "Unified Description" Requirement, 54 KY. L.J. 190 (1965).

- See Conmar Prods. Corp. v. Universal Slide Fastener Co., 172 F.2d 150, 157 (2d Cir. 1949); Sperry Rand Corp. v. Rothlein, 241 F. Supp. 549, 564 (D. Conn. 1964); Tempo Instrument, Inc. v. Logitek, Inc., 229 F. Supp. 1, 4 (E.D.N.Y. 1964). See generally Schatzel, The Trade Secret Dilemma-Employers Beware: Are You Hiring an Employee or an Employee and a Law Suit?, 38 U. CoLO. L. REv. 311,312 (1966).

${ }^{7}$ See Aktiebolaget Bofors v. United States, 194 F.2d 145, 148 (D.C. Cir. 1951); Marcuse, The Protection of Trade Secrets: Theory and Practice, 36 CoNN. B.J. 348, 348-51 (1962).

${ }^{8}$ Aktiebolaget Bofors v. United States, supra note 7, at 147; see, e.g., REstateMrENT, TORTs \$ 757, comment a (1939); Stedman, Trade Secrets, 23 OHIo ST. L.J. 4, 5-8 (1962). - See Shellmar Products Co. v. Allen-Qualley Co., 87 F.2d 104, 106 (7th Cir. 1936); Developments in the Law-Competitive Torts, 77 HARV. L. REv. 888, 948-49, 953-55 (1964); cf. International News Service v. Associated Press, 248 U.S. 215, 236-40 (1918).

20 Burnett v. New York Cent. R.R., 380 U.S. 424, 428 (1965); Guaranty Trust Co. v. United States, 304 U.S. 126, 136 (1938); McDonald v. United States, 315 F.2d 796, 801 (6th Cir. 1963); see, e.g., Missouri, Kan. \& Tex. Ry. v. Harriman, 227 U.S. 657, 672 (1913); Federal Reserve Bank v. Atlanta Trust Co., 91 F.2d 283, 286 (5th Cir.), cert. denied, 302 U.S. 738 (1937).

${ }^{11}$ See, e.g., Kavanagh v. Noble, 332 U.S. 535, 539 (1947); Olin Mathieson Chem. Corp. v. United States, 265 F.2d 293, 296 (7th Cir. 1959); Overfield v. Pennroad Corp., 146 F.2d 889, 896 (3d Cir. 1944); Federal Reserve Bank v. Atlanta Trust Co., 91 F.2d 283, 286 (5th Cir.), cert. denied, 302 U.S. 738 (1937); REsTatemenT, TORTs $\$ 899$, comment $c$ (1939). 
point at which the harm giving rise to the claim occurs. ${ }^{12}$ Such a designation is particularly difficult in the case of trade secrets, for the injury seemingly occurs at the time of the misappropriation, although it may not manifest itself until the use at a later date. That is, while the overall purpose of the tort is the prevention of the commercial exploitation of another's trade secrets, the particular object of protection is the knowledge of the trade secret owner, since this knowledge is the only element needed before the appropriator would have an inexhaustible ability to exploit the secret. Under the contract theory of recovery, which controls when the trade secret is acquired lawfully but only for specified purposes, a new cause of action arises for each unauthorized use, since such uses are construed as a breach of an express or implied contract. ${ }^{13}$ On the other hand, under the tort theory of recovery, which is applicable when the trade secret is acquired without the express or implied permission of the owner, a claim clearly arises at the time of the misappropriation. ${ }^{14}$ Whether a right to relief equally results from each subsequent exploitation of the idea has been undecided. ${ }^{15}$ Arguably, the continued use after the misappropriation could be considered a continuing tort on the theory that each utilization by the misappropriator constitutes a separate harm, thereby causing the statute of limitations to begin running anew. ${ }^{16}$ Alternatively, if the fundamental harm lies solely in the acquisition of the trade secret by improper means, conceivably the statute of limitations should run from the initial misappropriation only. ${ }^{17}$ Decisions in analogous areas of the law, such as trademarks, ${ }^{18}$ antitrust, ${ }^{19}$ and certain aspects of personal injury ${ }^{20}$ and

\footnotetext{
${ }^{12}$ See Federal Reserve Bank v. Atlanta Trust Co., 91 F.2d 283, 286-87 (5th Cir.), cert. denied, 302 U.S. 738 (1937).

${ }^{13}$ E.g., Titcomb v. Norton Co., 208 F. Supp. 9, 15-16 (D. Conn. 1959), aff'd, 308 F.2d 253 (2d Cir. 1962); Aktiebolaget Bofors v. United States, 139 Ct. Cl. 642, 644.45, 153 F. Supp. 397, 399.400 (1957); Gordon v. United States, 134 Ct. Cl. 840, 844, 140 F. Supp. 263, 265 (1956).

14 See, e.g., Aktiebolaget Bofors v. United States, 194 F.2d 145, 147 (D.C. Cir. 1951); RESTATEMENT, TORTS $\$ 757$, comment a (1939).

${ }^{25}$ See, e.g., Aktiebolaget Bofors v. United States, supra note 14, at 147-48; Titcomb v. Norton Co., 208 F. Supp. 9, 15-16 (D. Conn. 1959), aff'd, 308 F.2d 253 (2d Cir. 1962); Sachs v. Cluett, Peabody \&. Co., 265 App. Div. 497, 501, 39 N.Y.S.2d 853, 857 (1943). ${ }^{10}$ Cf. R. J. Reynolds Tobacco Co. v. Hudson, 314 F.2d 776, 781 (5th Cir. 1963); Crummer Co. v. duPont, 223 F.2d 238, 247-48 (5th Cir. 1955).

${ }^{17}$ See Restatement, Torts $\$ 757$, comment $a$ (1939); cf. Norman Tobacco \& Candy Co. v. Gillette Safety Razor Co., 197 F. Supp. 333, 338 (N.D. Ala. 1960), aff'd, 295 F.2d 362 (5th Cir. 1961).

${ }_{18}$ E.g., Menendez v. Holt, 128 U.S. 514, 523 (1888); Midy v. Midy Labs., Inc., 77 U.S.P.Q. 429, 431 (N.Y. Sup. Ct. 1948).

${ }^{10}$ E.g., Crummer Co. v. duPont, 223 F.2d 238, $247-48$ (5th Cir. 1955); Momand v.
} 
nuisances, ${ }^{21}$ where the object of protection can be subjected to repeated injury, apparently support the continuing-tort approach because they suggest that a cause of action arises for each act of harm to the interest which the injured party has at stake. Nevertheless, the pertinence of the analogies depends on whether the injury caused by the continued use of the trade secret is a separate harm to the interest being protected or merely a consequence of an original harm of misappropriation. If the principal concern of trade secret tort law is the employment of improper means to procure the secret, ${ }^{22}$ in contrast to its more general purpose; which is to protect against the consequential damages resulting from disclosure and adverse use, ${ }^{23}$ the continued exploitation would not be a separate harm unless the courts construe each use as a further occurrence of the unlawful acquisition.

Emphasizing that questions of fact were not being contested on appeal from a summary judgment, the court of appeals focused on the problem of whether the successive employment of a trade secret after misappropriation constituted a continuing tort. The court considered authorities cited by the district court and the parties ${ }^{24}$ but concluded that none of them was persuasive precedent. The court therefore examined three factors, the first of which was the nature of the tort involved. It determined that no recovery was to be allowed the original possessor of a trade secret against subsequent users where the secret had been destroyed by publication. However, the court concluded that this rule was not applicable to the misappropriator since he should not be allowed to cleanse his wrongful conduct by disclosure of the secret. Thus, once the secret is publicized, everyone can lawfully employ the information except one who originally obtained it unlawfully. Secondly, the court found

Universal Film Exchs., 172 F.2d 37, 49 (1st Cir. 1948), cert. denied, 336 U.S. 967 (1949). ${ }^{20}$ E.g., R. J. Reynolds Tobacco Co. v. Hudson, 314 F.2d 776, 781 (5th Cir. 1963); Pieczonka v. Pullman Co., 89 F.2d 353, 356 (2d Cir. 1937).

- ${ }^{21}$ E.g., Baltimore \& P.R.R. v. Fifth Baptist Church, 137 U.S. 568, 575-76 (1891); RestateMENT, TORTs, $\$ 899$, comment $d$ (1939).

${ }^{22}$ See Restatement, Torts $\$ 757$, comment a (1939); Developments in the LawCompetitive Torts, 77 HARv. L. REv. 888, 948-49 (1964).

${ }^{23}$ See Restatement, Torts $\$ 757$, comment $c$ (1939); Marcuse, supra note 7, at 350; cf. Note, 51 VA. L. REv. 917, 927-28 (1965).

" E.g., Aktiebolaget Bofors v. United States, 93 F. Supp. 131 (D.D.C. 1950), aff'd, 194 F.2d 145 (D.C. Cir. 1951), on remand, 139 Ct. Cl. 642, 153 F. Supp. 397 (1957); Sachs v. Cluett, Peabody \& Co., 265 App. Div. 497, 39 N.Y.S.2d 853 (I943); REsTATEMENT, TORTS $\$ 757$ (1939). 
that other areas of the law which treat each harm to the plaintiff as a separate injury, such as antitrust, trademark, and continuing-tort cases, provide strong analogous support for considering each use of the trade secret as creating a separate injury and cause of action. Finally, the court evaluated several competing policy considerations: ${ }^{25}$ (l) the statute of limitations may never run for misappropriators of trade secrets if use of the secret is a continuing tort; ${ }^{2 B}$ (2) the owner of a trade secret should not be required to rush into court before he realizes substantial harm from the misappropriator's exploitation of the secret; ${ }^{27}$ (3) the purpose of the statute of limitations is to prevent litigation of stale claims; ${ }^{28}$ and (4) the misappropriator should not be allowed to profit by his wrongdoing. ${ }^{29}$ On balance, the court concluded without elaboration that the policy considerations, as well as the nature of the tort and precedents from analogous areas, favor the continuing-tort theory and, accordingly, that the statute of limitations should run separately for each utilization of the trade secret.

While employment of the continuing-tort doctrine to circumvent the statute of limitations is justifiable since each usage can be viewed as a separate harm, the employment of this concept does have some questionable aspects. Conceptually, if the wrongful appropriation of the secret is the primary basis of the harm, it is disputable that the owner should escape the running of the statute of limitations of this misappropriation by grounding his tort suit on the wrongful use of the trade secret. Furthermore, the desirable policy balance between mobility of ideas and protection of trade secrets is impaired, because theoretically the misappropriator cannot exploit his acquired ideas no matter what length of time has elapsed. Nevertheless, the court's decision places great emphasis on the wrongful use of the secret as opposed to the wrongful acquisition. It is not clear whether, in denominating that use a continuing tort, the court relied on policy considerations generally, on the conceptual justification that each use is a separate harm to the protected interest, or on both of these explanations. Regardless, there are significant advantages in

\footnotetext{
${ }^{25} 151$ U.S.P.Q. at 93. Compare Brief for Appellee, pp. 11, 15, with Brief for Appellant, pp. 13-14.

${ }^{20}$ See Brief for Appellee, p. 11.

${ }^{27}$ See Brief for Appellant, p. 14.

${ }^{28}$ See Brief for Appellee, p. 15.

${ }^{20}$ See Brief for Appellant, pp. 13-14.
} 
using the continuing-tort approach: owners are not forced to sue until injury from the harm occurs and thus are given greater protection; also, a heavy burden is placed on wrongdoers in a trade secret environment, a factor which should tend to discourage improper activity. Furthermore, the court left open the possibility that the harshness of the continuing-tort doctrine on misappropriators may be mitigated where the situation dictates. Thus, the court could (1) determine that the owner had released the trade secret to the public; (2) decide that the damages were nominal; or (3) apply the doctrine of laches to disallow any equitable relief ${ }^{30}$ or to operate absolutely where there is no applicable statute of limitations. ${ }^{31}$ Hence, by employing a flexible and pragmatic version of the continuing-tort concept, when the case dictates the courts can provide the legal justification for punishing wrongdoers and thereby extend greater protection to owners of trade secrets.

\footnotetext{
${ }^{80}$ E.g., Reconstruction Fin. Corp. v. Harrison \& Crosfield, Ltd., 204 F.2d 366, 370 (2d Cir.), cert. denied, 346 U.S. 854 (1953); see Hoehn v. Crews, 144 F.2d 665 (10th Cir.), cert. denied, 329 U.S. 773 (1944); cf. United States v. Manufacturers Hanover Trust Co., 229 F. Supp. 544 (S.D.N.Y. 1964).

${ }^{21}$ E.g., Royal Air Properties, Inc. v. Smith, 312 F.2d 210, 214 (9th Cir. 1962).
} 